Florian Lejuste, MD

Laure Thomas, MD

Géraldine Picard

Virginie Desestret, MD,

$\mathrm{PhD}$

François Ducray, MD,

$\mathrm{PhD}$

Veronique Rogemond,

$\mathrm{PhD}$

Dimitri Psimaras, MD

Jean-Christophe Antoine, MD

Jean-Yves Delattre, MD

Laurent Groc, PhD

Marion Leboyer, MD,

$\mathrm{PhD}$

Jerome Honnorat, MD, $\mathrm{PhD}$

Correspondence to

Dr. Honnorat:

jerome.honnorat@chu-lyon.fr

Supplemental data at Neurology.org/nn

\title{
Neuroleptic intolerance in patients with anti-NMDAR encephalitis
}

\section{OPEN}

\section{ABSTRACT}

Objective: To precisely describe the initial psychiatric presentation of patients with anti-NMDA receptor (NMDAR) antibodies encephalitis (anti-NMDAR encephalitis) to identify potential clues enhancing its early diagnosis.

Methods: We retrospectively studied the French Reference Centre medical records of every adult patient with anti-NMDAR encephalitis to specify the patients' initial psychiatric symptoms leading to hospitalization in a psychiatric department and the reasons underlying the diagnosis of antiNMDAR encephalitis.

Results: The medical records of 111 adult patients were reviewed. Psychiatric features were the initial presentation in 65 patients (59\%). Among them, several psychiatric manifestations were observed, including visual and auditory hallucinations ( $n=26,40 \%)$, depression $(n=15,23 \%)$, mania ( $n=5,8 \%)$, acute schizoaffective episode $(n=15,23 \%)$, and eating disorder or addiction ( $n$ $=4 ; 6 \%)$. Forty-five patients ( $40 \%$ of total cohort) were first hospitalized in a psychiatric institution (91\% women), with a median duration of stay of 9 days (range $0.25-239$ days). Among them, 24 patients (53\%) had associated discreet neurologic signs at the first evaluation, while 17 additional patients (38\%) developed neurologic signs within a few days. Twenty-one patients (47\%) were transferred to a medical unit for a suspicion of antipsychotic intolerance characterized by high temperature, muscle rigidity, mutism or coma, and biological results suggesting rhabdomyolysis.

Conclusions: Several psychiatric presentations were observed in patients with anti-NMDAR encephalitis, although none was specific; however, patients, mostly women, also had discreet neurologic signs that should be carefully assessed as well as signs of antipsychotic intolerance that should raise suspicion for anti-NMDAR encephalitis. Neurol Neuroimmunol Neuroinflamm 2016;3:e280; doi: 10.1212/NXI.0000000000000280

\section{GLOSSARY}

CPK = creatine phosphokinase; DSM-IV = Diagnostic and Statistical Manual of Mental Disorders, 4th edition; DSM-5 = Diagnostic and Statistical Manual of Mental Disorders, 5th edition; ECT = electroconvulsive therapy; NMDAR = NMDA receptor; NMS = neuroleptic malignant syndrome.

Encephalitis with anti-NMDA receptor (NMDAR) antibodies (anti-NMDAR encephalitis) was first described in 2007 as a paraneoplastic syndrome in young women with ovarian teratoma, ${ }^{1}$ and it is now a widely recognized autoimmune synaptic disease. ${ }^{2}$ Anti-NMDAR encephalitis contributes to the novel links between immunology and psychiatry, especially in the developing area of autoimmune factors in classically conceived psychiatric diseases. ${ }^{3,4}$

Since 2007, several studies have extensively described the clinical and neuropsychiatric presentations of the disease. ${ }^{5-10}$ It affects children and young adults, especially women, and is generally

\footnotetext{
From Université Paris-Est (F.L., M.L.), INSERM U955, Laboratoire Psychiatrie Translationnelle, et AP-HP, DHU Pe-PSY, Pole de Psychiatrie et d'Addictologie des Hôpitaux Universitaires Henri Mondor, et Fondation FondaMental, Créteil; French Reference Center on Paraneoplastic Neurological Syndrome (L.T., G.P., V.D., F.D., V.R., D.P., J.-C.A., J.-Y.D., J.H.), Hospices Civils de Lyon, Hôpital Neurologique, Bron; Institut NeuroMyoGene (INMG) INSERM U1217/CNRS UMR 5310 (L.T., V.D., F.D., V.R., J.-C.A., J.H.), Lyon; Université de Lyon-Université Claude Bernard Lyon 1 (L.T., V.D., F.D., J.H.); AP-HP (D.P., J.-Y.D.), Groupe Hospitalier Pitié-Salpêtrière, Service de Neurologie 2-Mazarin, Paris; Service de Neurologie (J.-C.A.), CHU de Saint-Etienne et Université de Lyon, Saint-Etienne; Inserm (J.-Y.D.), U 1127, CNRS, UMR 7225, ICM, Sorbonne Universités, UPMC Univ Paris 06, UM 75 Paris; and Université de Bordeaux (L.G.), Interdisciplinary Institute for Neuroscience, UMR 5297, France.

Funding information and disclosures are provided at the end of the article. Go to Neurology.org/nn for full disclosure forms. The Article Processing Charge was paid by INSERM ADR O5, Lyon, France.

This is an open access article distributed under the terms of the Creative Commons Attribution-NonCommercial-NoDerivatives License 4.0 (CC BYNC-ND), which permits downloading and sharing the work provided it is properly cited. The work cannot be changed in any way or used commercially.
} 
characterized by an association of psychotic symptoms, epilepsy, abnormal movements, and amnesia. ${ }^{2,10}$ Its psychiatric presentation generally precedes neurologic signs and symptoms, which explains why patients are often first hospitalized in psychiatric departments before being transferred to medical care units. ${ }^{2,10}$ Many publications even suggest the presence of an isolated psychiatric presentation, ${ }^{8,11-13}$ which may reduce the chances of a correct diagnosis and specific treatment. The prognosis seems to depend on the rapidity of the initiation of an immunomodulatory treatment. ${ }^{2}$ Thus, a more precise description of initial psychiatric symptoms may help physicians to consider this diagnosis, and look for anti-NMDAR antibodies. Thus, in order to improve early identification of anti-NMDAR encephalitis when patients have an initial psychiatric presentation, the aim of this retrospective study was to precisely describe the initial clinical signs and symptoms that led to hospitalization in a psychiatric department and the reasons underlying the exploration of anti-NMDAR encephalitis hypothesis.

METHODS Patient selection. All the patients diagnosed with anti-NMDAR encephalitis in the French Autoimmune Encephalitis and Paraneoplastic Neurologic Syndrome Reference Center from October 2007 to October 2014 were included in the study. For anti-NMDAR encephalitis to be considered, the patients must be positive for immunoglobulin G-NMDAR in the CSF and fulfill the following previously established and now internationally recognized criteria $^{2,10,14}$ : (1) CSF samples must produce a specific pattern of neuropil rat brain hippocampus immunostaining and (2) CSF

\begin{tabular}{ll}
\hline Table $1 \quad$ Psychiatric features of the 65 patients \\
$\begin{array}{ll}\text { Signs and symptoms, syndromes, and patient } \\
\text { complaints }\end{array}$ & $\begin{array}{l}\text { No. (\% of } 65 \text { patients with psychiatric } \\
\text { symptoms) }\end{array}$ \\
Hallucinations (visual, auditory) & $26(40)$ \\
Depressive symptoms & $15(23)$ \\
Manic symptoms & $5(8)$ \\
Persecutory ideation & $5(8)$ \\
Mystical ideas & $4(6)$ \\
Unspecified delusions & 2 \\
Isolated dissociation & 2 \\
Erotomania & 1 \\
Paranoid symptoms & 1 \\
Anorexia nervosa & 1 \\
Bulimia & 1 \\
Addictive disorder & 1 \\
Post traumatic stress disorder & 1
\end{tabular}

samples must yield a positive cell-based assay on HEK293 cells expressing both GluN1 and GluN2B subunits of the NMDAR (figure e-1 at Neurology.org/nn). 2,10,14

Standard protocol approvals, registrations, and patient consents. Written consent was obtained from all patients for analysis of samples for research purposes, review of clinical information, and publication, and this study was approved by the Institutional Review Board of the University Claude Bernard Lyon 1 and Hospices Civils de Lyon. Samples were deposited in the collection of biological samples named Neurobiotec registered as the Biobank of the Hospices Civils de Lyon.

Clinical data collection. Even if all the anti-NMDAR antibodies were identified in our reference center, most of the patients in our cohort were not hospitalized in our department. Thus, for every patient with a confirmed diagnosis of anti-NMDAR encephalitis, clinical and paraclinical information were collected since October 2007 by phone and mail. Information regarding all clinical and psychiatric signs and symptoms and case evolution consisted of a medical record. In November 2014, we systematically and retrospectively studied every medical record in the database involving patients aged 16 years or older at the time of diagnosis. We excluded children from this study to avoid differences in the clinical management of psychiatric symptoms between children and adults in France. The following information was recorded: age, sex, initial and subsequent clinical presentations, detailed psychiatric and neurologic signs and symptoms before adequate treatment and during follow-up, psychiatric hospitalization and duration, psychotropic treatments prescribed, reasons for a secondary transfer to a medical or intensive care unit, and presence of an ovarian teratoma.

Psychiatric presentations were defined as presence of mood symptoms/disorder, eating disorder, anxiety symptoms/disorder, psychotic symptoms, delusion, or hallucination before prescription of an immunomodulatory treatment or during follow-up. Isolated agitation or confusion was not considered as a psychiatric presentation. Isolated psychiatric presentation was defined as psychiatric symptoms without any documented neurologic clinical signs and symptoms. Antipsychotic drug intolerance was defined as a serious drug adverse event occurring when antipsychotics were prescribed, such as fever, decreased alertness, or unusual extrapyramidal rigidity.

RESULTS Patients' initial signs and symptoms. A total of 175 medical records of patients with anti-NMDAR encephalitis were available in the French database. We excluded 47 patients because they were younger than 16 years and 17 others because of insufficient medical information in the case notes. Each of the 111 patients included had their first evaluation in an emergency department. Median age was 24 years (16-76 years), and 95 were women (86\%). Sixty-five of 111 (58.6\%) presented or reported various psychiatric symptoms. The complaints, neurologic signs and symptoms, or syndromes are summarized in table 1.

The majority of the patients $(n=68 ; 61.3 \%)$ were immediately hospitalized in a medical unit (internal medicine or neurology) or intensive care department, and 43 patients $(38.7 \%)$ were first hospitalized in psychiatric departments. Among the 68 patients hospitalized in a medical unit, 2 were secondarily transferred to a psychiatric department before they were finally correctly diagnosed. The reasons for an admission to 
psychiatry for these 2 patients were "acute psychotic episode" and "psychogenic nonepileptic seizures."

Characteristics of patients hospitalized in psychiatric departments. A total of 45 patients (40.5\%) were hospitalized in psychiatric departments ( 43 first admitted and 2 secondarily transferred). The majority of these patients were women ( $\mathrm{n}=41 ; 91 \%)$. There was no significant difference in admission rate in psychiatry between men and women (test $\chi^{2}, p=0.35$ ). Median age in these 45 patients was 24 years (17-48 years). For the majority of patients, it was their first episode of psychiatric symptoms $(\mathrm{n}=39 ; 87 \%)$. However, 6 patients $(13 \%)$ had a previous psychiatric episode, and for all of these cases, it was retrospectively suspected that they had previously undiagnosed anti-NMDAR encephalitis (see table e-1 for details). More than half of the 43 patients first hospitalized in psychiatric services $(\mathrm{n}=22 ; 51.1 \%)$ had one or more neurologic symptoms observed during their first emergency department evaluation. These signs and symptoms included headaches $(\mathrm{n}=8)$, confusion or spatial/ temporal disorientation $(\mathrm{n}=7)$, anterograde amnesia $(\mathrm{n}=5)$, tonic-clonic seizure $(\mathrm{n}=5)$, paresthesia $(\mathrm{n}=3)$, shivers or abnormal movements $(\mathrm{n}=2)$, aphasia or dysarthria $(\mathrm{n}=2)$, and cognitive impairment $(\mathrm{n}=1)$.

Figure 1 Reasons for transfer of the $\mathbf{4 5}$ patients hospitalized in the psychiatry department

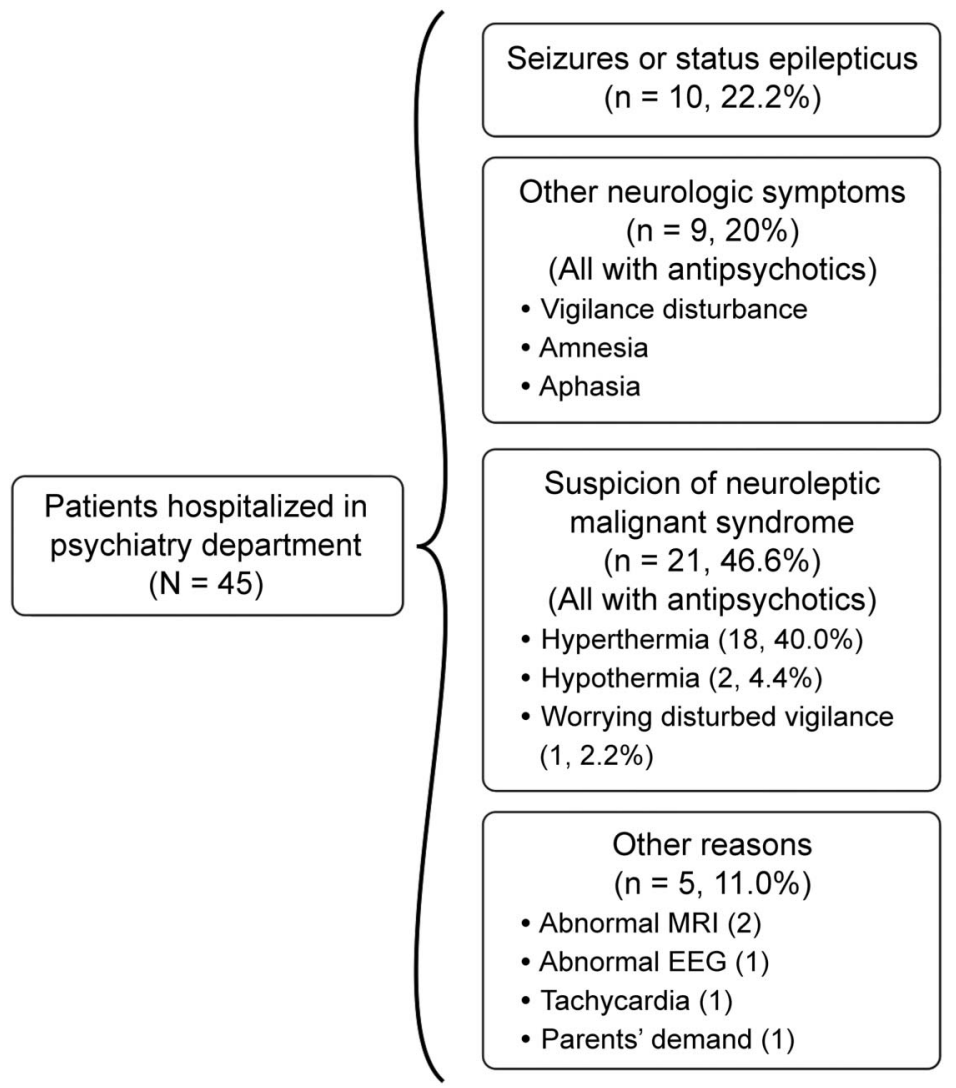

Reasons for transfer from psychiatric departments. Every patient who was initially hospitalized in psychiatry was transferred to another medical unit, most typically an intensive care unit, because another diagnosis than psychiatric disease was suspected but the diagnosis of anti-NMDAR encephalitis was not made at this stage. The reasons for the transfers were known for all 45 patients and are summarized in figure 1 .

Interestingly, for one patient, the only abnormal neurologic sign leading to transfer was a pure anterograde amnesia detected only after a discussion with her parents and a clinical examination. This young woman had been treated for 1.5 years with a diagnosis of schizophrenia and was hospitalized after a second episode of abnormal behavior (table e-1, patient 2).

Among the 21 patients transferred for suspicion of antipsychotic intolerance (table 2), 18 (86\%) had a temperature above $38.5^{\circ} \mathrm{C}$ associated with decreased alertness $(n=9)$, coma $(n=2)$, catatonia $(n=3)$, or muscular rigidity $(n=6)$. For all of these patients, documented evidence showed that antipsychotic drugs were administered hours or days before the emergent high temperature, suggesting neuroleptic malignant syndrome (NMS). Biological data were available in 13 patients (table 2). Creatine phosphokinase (CPK) level was available for 10 patients and suggested rhabdomyolysis (CPK $>1,000 \mathrm{UI} / \mathrm{L}$ ) in 7 patients (range 105-4,495 UI/L, median 1,513 UI/L, $\mathrm{n}=15-130$ UI/L). Serum sodium was available for 10 patients and 7 patients had hypernatremia $\left(\mathrm{Na}^{+} 133-160 \mathrm{mEq} / \mathrm{L}\right.$, median $148 \mathrm{mEq} / \mathrm{L}, \mathrm{n}=135-145 \mathrm{mEq} / \mathrm{L})$. Leukocyte count was available in 10 patients, and elevated in all patients, without evidence of infection (leukocytes 12-23 G/L, median 14.9 G/L, n = 4-10 G/L). Antipsychotic drugs were either first-generation (loxapine, cyamemazine, levomepromazine, zuclopenthixol, haloperidol) or second-generation (risperidone, olanzapine, aripiprazole), with 7 patients receiving drugs from both generations simultaneously. We did not identify any differences in the tolerance between first- and second-generation antipsychotics. Three other patients were transferred with a suspicion of NMS: 2 with hypothermia $\left(33^{\circ} \mathrm{C}\right.$ and $30.5^{\circ} \mathrm{C}$, respectively), and 1 with a significantly disturbed level of vigilance (table 2). In the entire series, patients who received antipsychotic drugs developed fever more frequently than patients who did not (19 of 36 patients [53\%] vs 11 of 75 patients [15\%], $p<0.0001$; Fisher exact test).

For the remaining 5 patients (11\%), the reasons for transfer were an abnormal brain MRI with nonspecific fluid-attenuated inversion recovery hypersignals for 2 cases, with one performed prior to a planned course of electroconvulsive therapy (ECT) and the other to explore the reasons behind self-mutilation. In another case, an EEG proved abnormal. Of the last 2 patients, one had tachycardia, with a suspicion of pulmonary 


\begin{tabular}{|c|c|c|c|c|c|c|c|c|}
\hline Patient & Sex & $\begin{array}{l}\text { Age at } \\
\text { diagnosis, } y\end{array}$ & Detailed psychiatric signs and symptoms & Reason for transfer & $\begin{array}{l}\text { Duration of stay } \\
\text { in psychiatry }\end{array}$ & $\begin{array}{l}\text { Neurologic signs and } \\
\text { symptoms }\end{array}$ & Antipsychotic received & $\begin{array}{l}\text { Presence } \\
\text { of ovarian } \\
\text { teratoma }\end{array}$ \\
\hline 1 & $\mathrm{~F}$ & 21 & Mystical ideas, catatonia & $\begin{array}{l}\text { Decreased alertness, hyperthermia, epilepsy; } \\
\text { CPK: } 105 \mathrm{UI} / \mathrm{L} ; \mathrm{WBC}: 18 \times 10^{9} / \mathrm{L}\end{array}$ & $5 \mathrm{wk}$ & $\begin{array}{l}\text { Dyskinesia, epilepsy, } \\
\text { decreased alertness }\end{array}$ & $\begin{array}{l}\text { Zuclopenthixol, olanzapine, } \\
\text { amisulpride }\end{array}$ & - \\
\hline 2 & $\mathrm{~F}$ & 22 & $\begin{array}{l}\text { Euphoria, logorrhea, auditory hallucinations, megalomania, } \\
\text { delusion, aggressive behavior }\end{array}$ & $\begin{array}{l}\text { Mutism, catatonia, hyperthermia } 40^{\circ} \mathrm{C} ; \\
\mathrm{CPK}: 3,180 \mathrm{UI} / \mathrm{L} ; \mathrm{WBC}: 14 \times 10^{\circ} / \mathrm{L}_{i} \\
\mathrm{Na}+149 \mathrm{mEq} / \mathrm{L}\end{array}$ & 4 wk & Decreased alertness & $\begin{array}{l}\text { Risperidone, } \\
\text { levomepromazine, } \\
\text { aripiprazole, cyamemazine }\end{array}$ & - \\
\hline 3 & M & 25 & Psychotic symptoms with delusion & $\begin{array}{l}\text { Paradoxical agitation after antipsychotic } \\
\text { drugs, hyperthermia } 40^{\circ} \mathrm{C} ; \mathrm{CPK}: 1,369 \mathrm{UI} / \mathrm{L} ; \\
\text { WBC: } 15.8 \times 10^{\circ} / \mathrm{L} ; \mathrm{Na}+146 \mathrm{mEq} / \mathrm{L}\end{array}$ & A few hours & $\begin{array}{l}\text { Tonic-clonic epilepsy, } \\
\text { abnormal movements } \\
\text { left hand }\end{array}$ & Haloperidol & - \\
\hline 4 & $\mathrm{~F}$ & 45 & Auditory and olfactory hallucinations & $\begin{array}{l}\text { Hyperthermia } 39^{\circ} \mathrm{C} \text {, confusion, headaches; } \\
\text { CPK: } 2,680 \mathrm{UI} / \mathrm{L}\end{array}$ & $10 d$ & $\begin{array}{l}\text { Abnormal movements } \\
\text { (feet), decreased } \\
\text { alertness }\end{array}$ & $\begin{array}{l}\text { Levomepromazine, } \\
\text { olanzapine }\end{array}$ & + \\
\hline 5 & $\mathrm{~F}$ & 20 & Posttraumatic stress disorder, then persecutory ideas & $\begin{array}{l}\text { Hypothermia } 30.5^{\circ} \mathrm{C} \text {, Glasgow score: } 9 ; \mathrm{Na}+ \\
157 \mathrm{mEq} / \mathrm{L}\end{array}$ & $5 d$ & $\begin{array}{l}\text { Dyskinesia, } \\
\text { dysautonomia }\end{array}$ & Risperidone & + \\
\hline 6 & $\mathrm{~F}$ & 40 & Visual hallucinations, anxiety with derealization & $\begin{array}{l}\text { Hyperthermia, catatonia; WBC: }>14 \times 10^{9} / \mathrm{L} ; \\
\mathrm{Na}+152 \mathrm{mEq} / \mathrm{L}\end{array}$ & $8 d$ & $\begin{array}{l}\text { Dyskinesia, decreased } \\
\text { alertness, muscular } \\
\text { rigidity }\end{array}$ & Cyamemazine, risperidone & - \\
\hline 7 & $\mathrm{~F}$ & 29 & Visual and auditory hallucinations, catatonia & $\begin{array}{l}\text { Hypothermia } 33^{\circ} \mathrm{C} \text {, catatonia; WBC: } 16.3 \times \\
10^{\circ} / \mathrm{L} ; \mathrm{Na}+159 \mathrm{mEq} / \mathrm{L}\end{array}$ & $4 d$ & Dyskinesia & Cyamemazine & + \\
\hline 8 & $\mathrm{~F}$ & 24 & $\begin{array}{l}\text { Compulsive shopping, mood elation, hyperactivity; delusions } \\
\text { with auditory hallucinations }\end{array}$ & $\begin{array}{l}\text { Hyperthermia } 39^{\circ} \mathrm{C} \text {, decreased alertness; } \\
\mathrm{Na}+142 \mathrm{mEq} / \mathrm{L}\end{array}$ & $12 d$ & $\begin{array}{l}\text { Tonic-clonic seizure, } \\
\text { decreased alertness }\end{array}$ & $\begin{array}{l}\text { Aripiprazole, loxapine, } \\
\text { diazepam }\end{array}$ & - \\
\hline 9 & $\mathrm{~F}$ & 32 & $\begin{array}{l}\text { 1st psychotic episode in } 1999 \text { : then hyperthermia, treated with } \\
\text { corticosteroids and remission; same episode in } 2003 \text {; in } 2009 \text { : } \\
\text { sadness with anorexia, anxiety, and negative thoughts, then } \\
\text { persecution ideas }\end{array}$ & Hyperthermia; bio: NA & $1 \mathrm{mo}$ & $\begin{array}{l}\text { Dyskinesia, muscular } \\
\text { rigidity }\end{array}$ & Olanzapine & - \\
\hline 10 & $\mathrm{~F}$ & 26 & $\begin{array}{l}\text { Behavior changes, diagnosis of first psychotic episode with no } \\
\text { precision }\end{array}$ & $\begin{array}{l}\text { Hyperthermia; CPK: } 202 \text { UI/L; WBC: } 12.4 \times \\
10^{\circ} / \mathrm{L} ; \mathrm{Na}+140 \mathrm{mEq} / \mathrm{L}\end{array}$ & $5 d$ & $\begin{array}{l}\text { Dysautonomia, } \\
\text { muscular rigidity }\end{array}$ & Zuclopenthixol & + \\
\hline 11 & $\mathrm{~F}$ & 22 & Behavior changes, agitation & $\begin{array}{l}\text { Hyperthermia, abnormal movements; CPK: } \\
1,657 \mathrm{UI} / \mathrm{L} ; \mathrm{WBC}: 15.8 \times 10^{9} / \mathrm{L} ; \mathrm{Na}+ \\
147 \mathrm{mEq} / \mathrm{L}\end{array}$ & $8 d$ & Abnormal movements & Loxapine, quetiapine & + \\
\hline 12 & $\mathrm{~F}$ & 31 & Agitation, derealization, delusion with auditory hallucinations & Hyperthermia; bio: NA & $3 w k$ & $\begin{array}{l}\text { Language disorders, } \\
\text { confusion }\end{array}$ & Haloperidol & - \\
\hline 13 & $\mathrm{~F}$ & 23 & Visual hallucinations, insomnia & $\begin{array}{l}\text { Hyperthermia + coma; WBC: } 23.6 \times 10^{9} / \mathrm{L} ; \\
\mathrm{Na}+160 \mathrm{mEq} / \mathrm{L}\end{array}$ & A few hours & $\begin{array}{l}\text { Epilepsy, confusion, } \\
\text { dyskinesia }\end{array}$ & $\begin{array}{l}\text { Unspecified antipsychotic } \\
\text { drugs }\end{array}$ & - \\
\hline 14 & M & 20 & Visual and auditory hallucinations, sexual disinhibition & Catatonia; CPK $>1,000 \mathrm{UI} / \mathrm{L}$ & $12 d$ & $\begin{array}{l}\text { Amnesia, epilepsy, } \\
\text { confusion, decreased } \\
\text { alertness }\end{array}$ & Olanzapine, loxapine & - \\
\hline 15 & $\mathrm{~F}$ & 24 & Anxiety, aggressive behavior, logorrhea, elation, echolalia & $\begin{array}{l}\text { Hyperthermia, decreased alertness; } \\
\text { CPK: } 438 \text { UI/L; WBC }>13 \times 10^{\circ} / \mathrm{L}\end{array}$ & $6 \mathrm{~d}$ & $\begin{array}{l}\text { Epilepsy, dyskinesia, } \\
\text { dysautonomia }\end{array}$ & Risperidone & + \\
\hline 16 & M & 18 & $\begin{array}{l}\text { Persecution ideas, suicide attempt (defenestration), visual } \\
\text { hallucinations }\end{array}$ & $\begin{array}{l}\text { Hyperthermia, abnormal movements, } \\
\text { decreased alertness; bio: NA }\end{array}$ & $6 \mathrm{~d}$ & $\begin{array}{l}\text { Decreased alertness, } \\
\text { abnormal movements }\end{array}$ & Loxapine succinate & - \\
\hline 17 & $\mathrm{~F}$ & 24 & Auditory hallucinations, anxiety, delusion & $\begin{array}{l}\text { Hyperthermia, decreased alertness; } \\
\mathrm{CPK}: 2,790 \mathrm{UI} / \mathrm{L} ; \mathrm{WBC}: 12.0 \times 10^{9} / \mathrm{L} ; \\
\mathrm{Na}+133 \mathrm{mEq} / \mathrm{L}\end{array}$ & $6 d$ & $\begin{array}{l}\text { Decreased alertness, } \\
\text { confusion }\end{array}$ & Loxapine & + \\
\hline
\end{tabular}




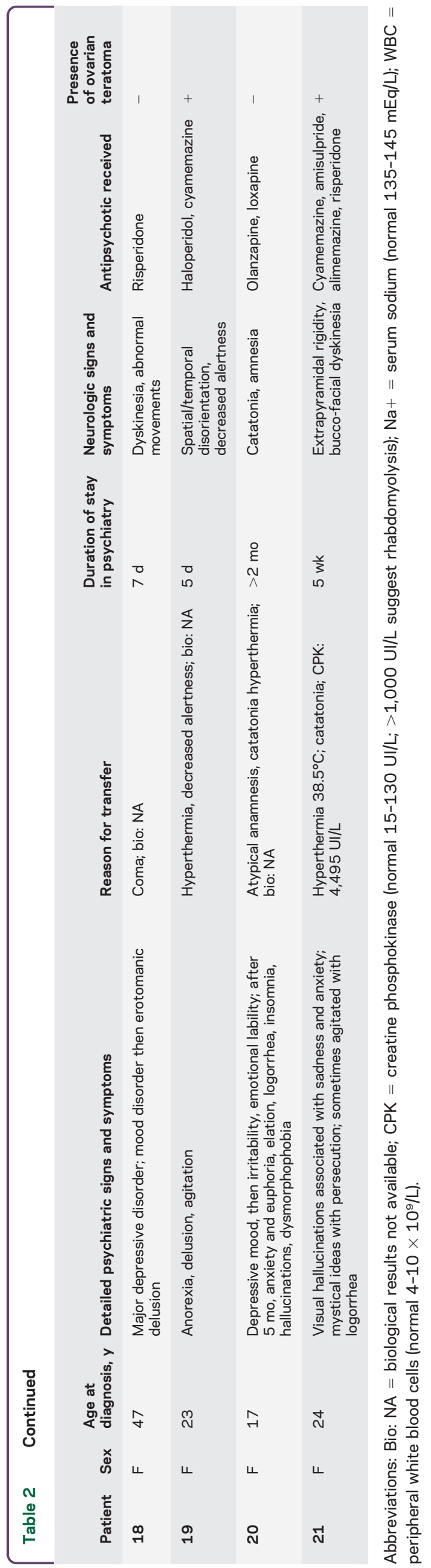

embolism, while the other patient was transferred due to parental demand.

Duration of psychiatric hospitalization. Hospitalization in psychiatry lasted from 6 hours to several months. The duration was precisely known for all the patients (median duration 9 days, range 0.25-239 days). Nine patients were hospitalized more than 4 weeks $(30,35$, $35,60,74,87,90$, and 239 days, respectively, and 1 patient had several hospitalizations and admission to day hospital in a total period of 13 months). Interestingly, one of these patients, hospitalized for 90 days, had a medical history of unspecified encephalitis, but the case notes indicated that the attending physicians did not consider a diagnosis other than depression. This patient presented with a severe major depressive disorder, which was resistant to psychotropic or antidepressant drugs. A transfer was finally organized 2 months later after an abnormal brain MRI was performed prior to a planned course of ECT.

Treatment and outcome. After the diagnosis of antiNMDAR encephalitis, all of the patients were treated with immunomodulators (combination of steroids, immunoglobulins, cyclophosphamide, or rituximab). We studied the outcome of the 109 patients, with a median follow-up time longer than 2 years (figure 2). The median time to total recovery (modified Rankin Scale score 1 or 0 ) was 9 months, and the total recovery rate was $90 \%$ at 24 months. We observed no differences in the recovery rate between patients who were first hospitalized in psychiatric institutions vs other medical departments or in the recovery rates of patients with or without antipsychotic drug intolerance.

DISCUSSION Overall, our data show, as suggested by other authors, ${ }^{7-13}$ that psychiatric presentations in patients with anti-NMDAR encephalitis are heterogeneous, with several different psychiatric signs, symptoms, or syndromes with no psychiatric clinical characteristics specific to anti-NMDAR encephalitis.

Our results also outline that emergency physicians, neurologists, and psychiatrists must systematically search for associated discreet neurologic signs and symptoms relevant to encephalitis in young patients with psychiatric symptoms. Indeed, more than half $(n=24)$ of the 45 patients hospitalized in psychiatric departments had neurologic signs at the first evaluation. Despite the presence of these comorbid elements, the patients were not correctly diagnosed or hospitalized in an appropriate unit and did not receive the medical investigations required for diagnosis of encephalitis. Many patients had a normal neuroimaging, which was misinterpreted to support a primary psychiatric etiology of symptoms and signs, but neuroimaging is frequently normal in anti-NMDAR encephalitis. ${ }^{2,11}$

An interesting observation was the very high rate of possible antipsychotic drug intolerance in our 


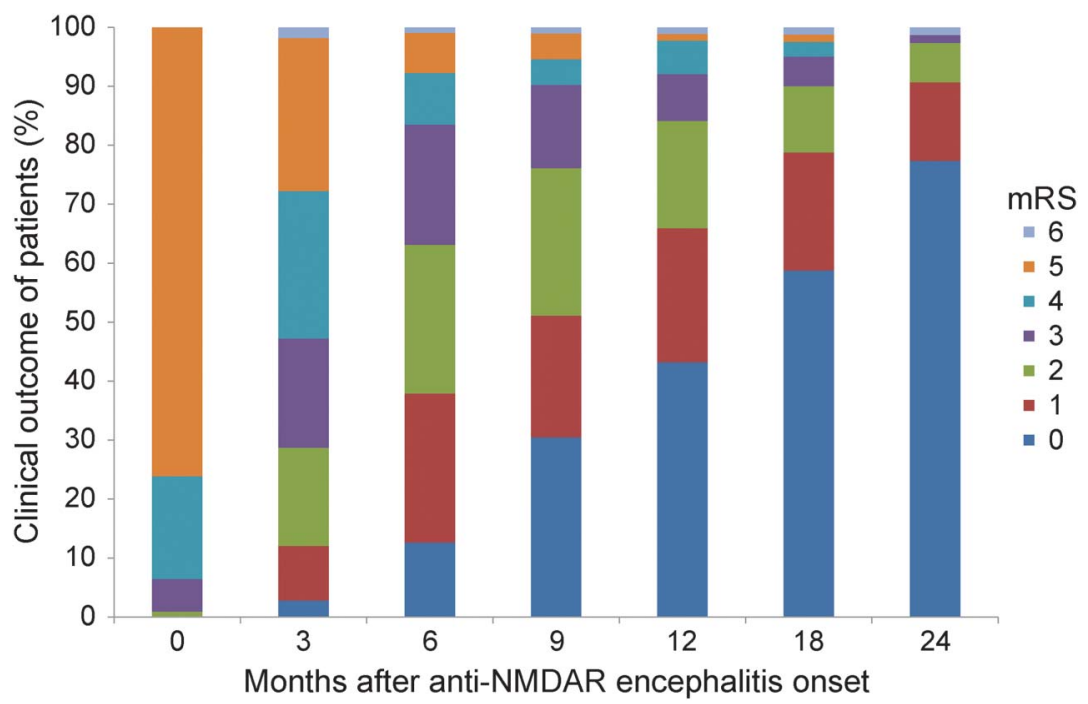

Clinical outcome of 109 adult patients measured with the modified Rankin Scale (mRS) at 0, 3, 6, 9, 12, 18, and 24 months after the onset of anti-NMDAR encephalitis.

series. Some previous publications have reported a similar phenomenon in a few case reports, ${ }^{15-18}$ but the extremely high rate in our cohort is unprecedented. In several medical records, psychiatrists had diagnosed NMS or malignant catatonia, which are extremely rare conditions that are reported in fewer than $0.1 \%$ of patients hospitalized in psychiatric institutions. ${ }^{19}$ In particular, it should be stressed that one patient presented with 3 previous psychiatric episodes, separated by many years, and for each episode, she had experienced severe intolerance to antipsychotic drugs.

DSM- $5^{20}$ and DSM-IV ${ }^{21}$ do not provide an exact list of criteria for NMS, and we did not have enough information on the 21 patients to strictly confirm the diagnosis of NMS, but the significantly high rate of fever with abnormal biological data in our patients receiving antipsychotic drugs and the absence of such clinical presentation in the group of patients who were not treated with antipsychotic drugs suggests the existence of a pathophysiologic overlap between NMS, malignant catatonia, and anti-NMDAR encephalitis.

Interestingly, hypofunction of glutamatergic neurotransmission has been proposed in the etiology of NMS, ${ }^{22}$ although amantadine, a weak NMDA receptor antagonist, improves NMS symptoms in a Parkinson disease model. ${ }^{23,24}$ Beyond the apparent contradiction of glutamatergic functioning, the pathophysiologic interplay between the NMDAR and dopaminergic receptors, and more generally monoamine signaling, emerges as a core mechanism in several neuropsychiatric disorders. Any alteration in NMDAR signaling at the neuronal surface (as reported in anti-NMDAR encephalitis ${ }^{25,26}$ ) can modify the trafficking and thus signaling of dopamine receptors, through direct interactions between receptors or intracellular signaling cascades. ${ }^{25-27}$ Thus, antipsychotic drugs could either alleviate or worsen NMDAR-based symptoms based on their range of action on the monoamine systems and our results suggest extreme caution in the use of antipsychotic drugs in patients with anti-NMDAR encephalitis. Clearly, suspicion of antipsychotic intolerance is a very important alarm to suspect anti-NMDAR encephalitis and may lead psychiatrists to investigate such a diagnosis.

Some limitations of the present study must be discussed. As a retrospective cohort study, selection bias and information bias may limit the strength of our results. Furthermore, physicians may have changed since 2007 and probably discuss more frequently the diagnosis of anti-NMDAR encephalitis in front of acute psychiatric symptoms. Our main result concerning neuroleptic intolerance is limited by the lack of more specific clinical and paraclinical details. Similarly, presence or absence of discreet neurologic or psychiatric signs and symptoms must be considered with caution due to possible variability in detailed examinations among patients.

\section{AUTHOR CONTRIBUTIONS}

Dr. Lejuste: analysis, interpretation of the data, drafting the manuscript for intellectual content. Dr. Thomas: acquisition of data. G. Picard: acquisition of data. Dr. Desestret: analysis and interpretation, critical revision of the manuscript for important intellectual content. Dr. Ducray: acquisition of data, critical revision of the manuscript for important intellectual content. Dr. Rogemond: acquisition of data. Dr. Psimaras: acquisition of data, critical revision of the manuscript for important intellectual content. Pr. Antoine: acquisition of data, critical revision of the manuscript for important intellectual content. Pr. Delattre: critical revision of the manuscript for important intellectual content. Dr. Groc: critical revision of the manuscript for important intellectual content. Pr. Leboyer: critical revision of the manuscript for important intellectual content. Pr. Honnorat: study concept and design, 
analysis and interpretation, critical revision of the manuscript for important intellectual content, study supervision.

\section{ACKNOWLEDGMENT}

The authors thank the patients for their participation. CSF samples were collected with the help of Neurobiotec Bank and the Hospices Civils de Lyon.

\section{STUDY FUNDING}

Agence Nationale de la Recherche (Automobil, 12SAMA01402), the Fédération pour la Recherche sur le Cerveau (FRC), INSERM, Institut National de la Santé et de la Recherche Médicale and Fondation FondaMental.

\section{DISCLOSURE}

F. Lejuste, L. Thomas, G. Picard, V. Desestret, F. Ducray, V. Rogemond, and D. Psimaras report no disclosures. J.-C.G. Antoine received travel funding from le Laboratoire Francais des Biotechnologies et du Fractionnement, le CSL Behring, Genzyme, is an associate editor for Revue Neurologique, Paris, and holds a patent for diagnostic test for anti-CV2/CRMP5 antibody detection. J.-Y. Delattre received travel funding from ECCO Meeting, is on the editorial board for The Oncologist, and received research support from Institut National du Cancer, Ligue Nationale contre le Cancer. L. Groc is on the editorial board for PLOS One and received research support from Agence National Recherche (Paris). M. Leboyer is on the editorial board for Acta Psychiatrica Scandinavica Schizophrenia Bulletin. Go to Neurology.org/ $\mathrm{nn}$ for full disclosure forms.

Received April 2, 2016. Accepted in final form June 27, 2016.

\section{REFERENCES}

1. Dalmau J, Tüzün E, Wu H, et al. Paraneoplastic anti-Nmethyl-D-aspartate receptor encephalitis associated with ovarian teratoma. Ann Neurol 2007;61:25-36.

2. Titulaer MJ, McCraken L, Gabilondo I. Treatment and prognostic factors for long-term outcome in patients with anti-NMDA receptor encephalitis: an observational cohort study. Lancet Neurol 2013;12:157-165.

3. Severance EG, Yolken RH, Eaton WW. Autoimmune diseases, gastrointestinal disorders and the microbiome in schizophrenia: more than a gut feeling. Schizophr Res 2014;176:S0920-S9964.

4. Kayser MS, Dalmau J. The emerging link between autoimmune disorders and neuropsychiatric disease. J Neuropsychiatry Clin Neurosci 2011;23:90-97.

5. Chapman MR, Vause HE. Anti-NMDA receptor encephalitis: diagnosis, psychiatric presentation, and treatment. Am J Psychiatry 2011;168:245-251.

6. Dalmau J, Kayser MS. Anti-NMDA receptor encephalitis in psychiatry. Curr Psychiatry Rev 2011;7:189-193.

7. Armangue T, Titulaer MJ, Malaga I. Pediatric anti-Nmethyl-D-aspartate receptor encephalitis: clinical analysis and novel findings in a series of 20 patients. J Pediatr 2013;162:850-856.

8. Zandi MS, Deakin JB, Morris K, et al. Immunotherapy for patients with acute psychosis and serum N-methyl Daspartate receptor (NMDAR) antibodies: a description of a treated case series. Schizophr Res 2014;160:193-195.

9. Zandi MS, Irani SR, Lang B, et al. Disease-relevant autoantibodies in first episode schizophrenia. J Neurol 2011; 258:686-688.
10. Dalmau J, Gleichman AJ, Hughes EG, et al. Anti-NMDAreceptor encephalitis: case series and analysis of the effects of antibodies. Lancet Neurol 2008;7:1091-1098.

11. Kayser MS, Titulaer MJ, Gresa-Arribas N, et al. Frequency and characteristics of isolated psychiatric episodes in anti$\mathrm{N}$-methyl-d-aspartate receptor encephalitis. JAMA Neurol 2013;70:1133-1139.

12. Creten C, Van der Zwann S, Blankespoor RJ, et al. Late onset autism and anti-NMDA-receptor encephalitis. Lancet 2011;378:98

13. Consoli A, Ronen K, An-Gourfinkel I, et al. Malignant catatonia due to anti-NMDA-receptor encephalitis in a 17-year-old girl: case report. Child Adolesc Psychiatry Ment Health 2011;5:15.

14. Viaccoz A, Desestret V, Ducray F, et al. Clinical specificities of adult male patients with NMDA receptor antibodies encephalitis. Neurology 2014;82:556-563.

15. Kuo YL, Tsai HF. Anti-NMDA receptor encephalitis with the initial presentation of psychotic mania. J Clin Neurosci 2012;19:896-898.

16. Mohammad SS, Wallace G, Ramanathan S, et al. Antipsychotic-induced akathisia and neuroleptic malignant syndrome in anti-NMDAR encephalitis. Ann Clin Psychiatry 2014;26: 297-298.

17. Punja M, Pomerleau AC, Devlin JJ, et al. Anti-N-methylD-aspartate receptor (anti-NMDAR) encephalitis: an etiology worth considering in the differential diagnosis of delirium. Clin Toxicol 2013;51:794-797.

18. Caroff SN, Campbell EC. Risk of neuroleptic malignant syndrome in patients with NMDAR encephalitis. Neurol Sci 2015;36:479-480.

19. Gelenberg AJ, Bellinghausen B, Wojcik JD, et al. A prospective survey of neuroleptic malignant syndrome in a short-term psychiatric hospital. Am J Psychiatry 1988;145:517-518.

20. American Psychiatric Association. Diagnostic and Statistical Manual of Mental Disorders, 5th Edition (DSM-5). Arlington: American Psychiatric Association; 2013.

21. American Psychiatric Association. Diagnostic and Statistical Manual of Mental Disorders, 4th Edition (DSM-IV). Washington, DC: American Psychiatric Association; 1994.

22. Carroll BT. The universal field hypothesis of catatonia and neuroleptic malignant syndrome. CNS Spectr 2000;5:26-33.

23. Weller M, Kornhuber JA. Rationale for NMDA receptor antagonist therapy of the neuroleptic malignant syndrome. Med Hypotheses 1992;38:329-333.

24. Kornhuber J, Weller M. Amantadine and the glutamate hypothesis of schizophrenia: experiences in the treatment of neuroleptic malignant syndrome. J Neural Transm Gen Sect 1993;92:57-65.

25. Mikasova L, De Rossi P, Bouchet D, et al. Disrupted surface cross-talk between NMDA and Ephrin-B2 receptors in antiNMDA encephalitis. Brain 2012;135:1606-1621.

26. Ladepeche L, Dupuis JP, Bouchet D, et al. Single-molecule imaging of the functional crosstalk between surface NMDA and dopamine D1 receptors. Proc Natl Acad Sci U S A 2013;110:18005-18010.

27. Porras G, Berthet A, Dehay B, et al. PSD-95 expression controls L-DOPA dyskinesia through dopamine D1 receptor trafficking. J Clin Invest 2012;122:3977-3989. 


\section{Neurology \\ Neuroimmunology \& Neuroinflammation}

Neuroleptic intolerance in patients with anti-NMDAR encephalitis

Florian Lejuste, Laure Thomas, Géraldine Picard, et al.

Neurol Neuroimmunol Neuroinflamm 2016;3;

DOI 10.1212/NXI.0000000000000280

This information is current as of August 29, 2016

\section{Updated Information \& Services}

References

Citations

Subspecialty Collections

Permissions \& Licensing

Reprints including high resolution figures, can be found at: http://nn.neurology.org/content/3/5/e280.full.html

This article cites 25 articles, 1 of which you can access for free at: http://nn.neurology.org/content/3/5/e280.full.html\#\#ref-list-1

This article has been cited by 8 HighWire-hosted articles: http://nn.neurology.org/content/3/5/e280.full.html\#\#otherarticles

This article, along with others on similar topics, appears in the following collection(s):

All Psychiatric disorders

http://nn.neurology.org//cgi/collection/all_psychiatric_disorders Encephalitis

http://nn.neurology.org//cgi/collection/encephalitis

Paraneoplastic syndrome

http://nn.neurology.org//cgi/collection/paraneoplastic_syndrome

Information about reproducing this article in parts (figures,tables) or in its entirety can be found online at:

http://nn.neurology.org/misc/about.xhtml\#permissions

Information about ordering reprints can be found online: http://nn.neurology.org/misc/addir.xhtml\#reprintsus

Neurol Neuroimmunol Neuroinflamm is an official journal of the American Academy of Neurology.

Published since April 2014, it is an open-access, online-only, continuous publication journal. Copyright $\odot$ 2016 American Academy of Neurology. All rights reserved. Online ISSN: 2332-7812.

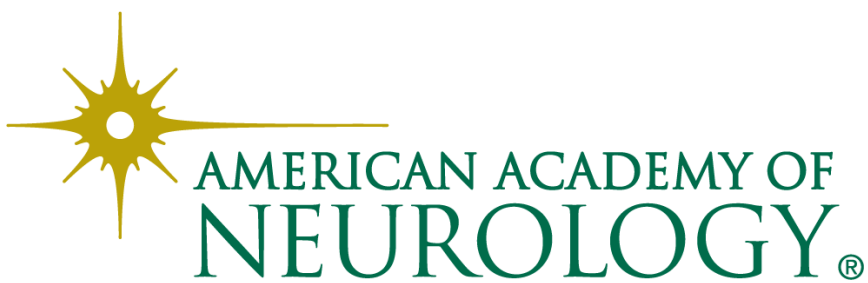

